\title{
19
}

\section{Austronesian Migration to Central Vietnam: Crossing over the Iron Age Southeast Asian Sea}

\author{
Mariko Yamagata and Hirofumi Matsumura
}

\begin{abstract}
The Sa Huynh culture, which spread over Central Vietnam during the early Metal Age, is generally associated with an Austronesian-speaking (Chamic) population. Solheim advocated the close similarity between pottery found at the Kalanay Cave in Masbate, Central Philippines, and the Sa Huynh culture in Central Vietnam. However, based on our recent archaeological research, Kalanay-type pottery is actually a feature of the jar burials at the Hoa Diem site that probably postdates Sa Huynh cultural sites. Solheim also found strikingly similar pottery from Samui Island in Southern Thailand that is quite different from Sa Huynh. The absence of a specific type of earring called lingling-o at Hoa Diem and Kalanay also suggests a chronological gap from the Sa Huynh culture. A bio-anthropological analysis of the Hoa Diem skeletons is consistent with a close affinity to insular Southeast Asians, suggesting long-distance cultural interaction and/or the demographic movement of Austronesian speakers across the South China Sea in the 1st and 2nd centuries AD.
\end{abstract}

\section{Introduction}

A focal point of Southeast Asian archaeology and anthropology has been the reconstruction of prehistoric maritime links. In prehistoric times, this area witnessed human migrations and movements that often involved major sea crossings. As Bellwood and Glover (2004: 5) described, 'Southeast Asia did not witness any truly independent development of early agriculture, urban civilisation, or literacy, but it did witness the oldest recorded maritime voyages by humans'.

Pleistocene seafarers could cross large expanses of open sea, as evidenced by the movement of early anatomically modern humans across Wallacea to Australia as far back as 50,000 years ago. Much later, Austronesian speakers (referred to simply as Austronesians from here on) based in Island Southeast Asia (ISEA) colonised the far-flung islands of the Indian Ocean and Oceania from Madagascar in the west to Easter Island in the east. Blust (1984-1985, 1996) and Bellwood (1997) reconstructed the overall linguistic and archaeological dispersal of Austronesians. A hypothesis on the homeland of Austronesian languages and the process of their dispersal was initially proposed by linguists and has significantly influenced the prehistoric archaeology of these regions. Bellwood has been working on verifying this hypothesis through archaeology and trying to reconstruct a complete history of the Austronesian dispersal that took place in various stages between 5,000 and 1,000 years ago (Bellwood 1997, 2004, 2005; Bellwood and Dizon 2005, 2008). His work suggests that the ancestors of the Austronesians originated in Southern China, 
and travelled to Taiwan - taking rice farming with them - probably by 5000 BP. Excavations on the Batanes Islands lying between Taiwan and Luzon identified possible evidence for the initial Neolithic dispersal out of Taiwan into the Northern Philippines by around 4000 BP (Bellwood and Dizon 2005, 2008, 2013). These Austronesians then proceeded to migrate south and east through the rest of the Philippine archipelago and into Sulawesi and Borneo before dispersing across the rest of ISEA and the Pacific.

Based on the linguistic work of Blust (1995), Bellwood described a branch of the Austronesian dispersal crossing over the South China Sea from Western Borneo to Vietnam around 2300 BP, perhaps made by people who spoke a language ancestral to Chamic (Bellwood 1997: 120-121). Chamic is actually the only Austronesian language spoken in Mainland Southeast Asia, being the language of the Chams, as well as some mountain dwellers presently living in Southern Vietnam and Cambodia.

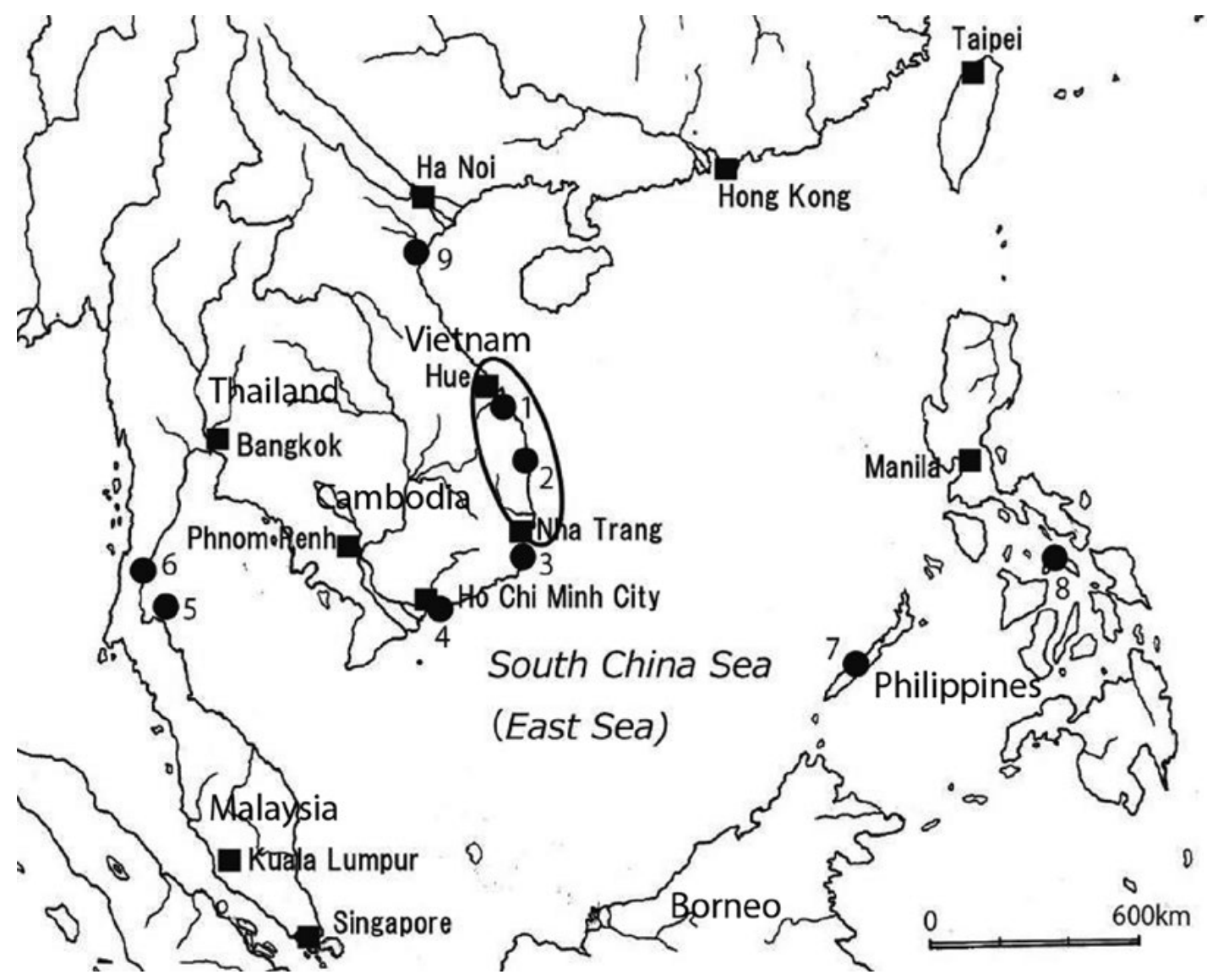

Figure 19.1 Locality map of sites relating to this chapter. Circle: Distribution sphere of the Sa Huynh culture in Vietnam.

(1) Lai Nghi, Hau Xa, An Bang, Go Ma Voi, Binh Yen; (2) Sa Huynh, Long Thanh; (3) Hoa Diem; (4) Giong Ca Vo; (5) Samui;

(6) Khao Sam Kaeo; (7) Tabon; (8) Kalanay; (9) Dong Son.

Source: M. Yamagata. 

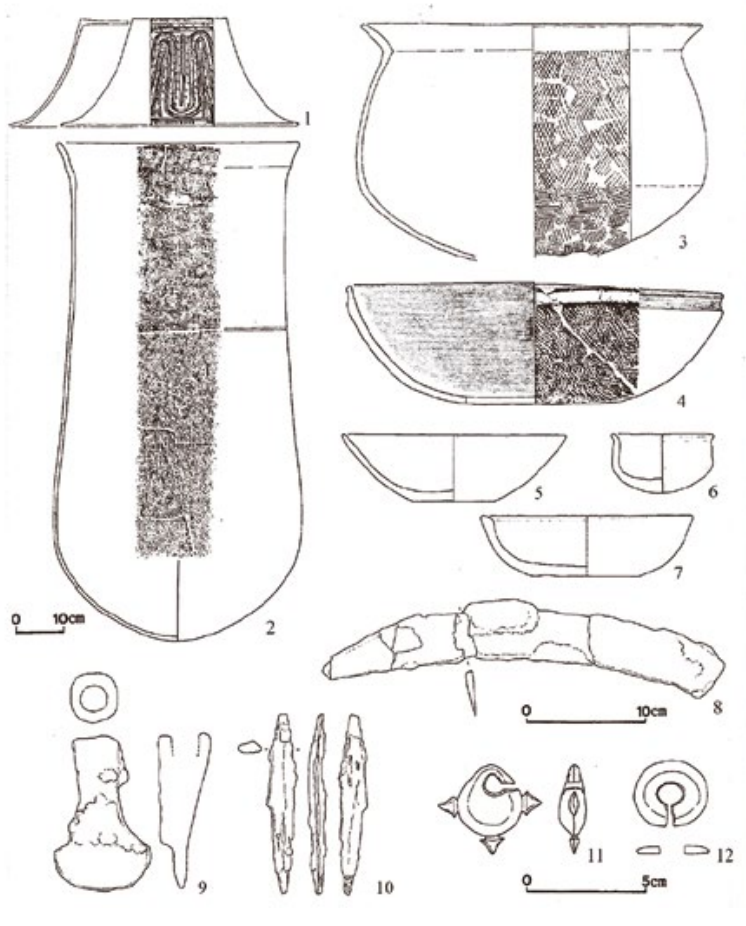

Figure 19.2 Typical jar, lid, and funerary goods of the Sa Huynh culture.

Burial No. M6 of Binh Yen (1, 13: lid; 2, 13: cylindrical burial jar; 3-7: pottery vessels; 8-10: iron tools; 11-12: stone earrings). Source: M. Yamagata.

Bellwood thus inferred that the Iron Age Sa Huynh culture in Central Vietnam (Figure 19.1) was associated with an Austronesian-speaking (Chamic) population that had arrived in that region from either Peninsular Malaysia or Borneo, as documented archaeologically by the Sa Huynh culture itself (Bellwood 1997: 271-272).

A unique characteristic of the Sa Huynh culture is its mortuary customs, with lidded jar burials (Figure 19.2). These are associated with funerary accessory goods, such as pottery, iron and bronze implements, and earrings and beads made of agate, carnelian, jade (nephrite), and glass (see Nguyen Kim Dung, Chapter 18, this volume). The Sa Huynh cemeteries are often found on sand dunes extending along coasts or rivers on the alluvial plains. Although the Sa Huynh culture is recognised as having possibly fallen into decline in the latter half of the first century AD, the timing of its emergence still remains uncertain (Yamagata 2007a). Vietnamese archaeologists consider Champa to have emerged indigenously from local Sa Huynh (Ha 1999: 341), and that Sa Huynh populations like their Champa successors were Austronesian speakers (Ha 1984-1985).

Solheim $(1984-1985,1992,2002,2006)$ proposed a different scenario from that of Bellwood with regards to the movements of Austronesians. Solheim $(2006: 60)$ initially coined the term 'Nusantao' or 'people of the south islands' to encompass speakers of Austronesian languages, but later used it to refer to a 'maritime-oriented trading people probably speaking an Austronesian language'. He maps the prehistoric networks of boat trading people, which he calls the Nusantao Maritime Trading and Communication Networks, extending from ISEA westward to Madagascar, northward to Korea and Japan, and eastward across the Pacific as far as Easter Island. His scenario of global-scale maritime culture evidenced through the widespread distribution of Nusantao in Southeast Asia is to some degree dependent on the accuracy of his identification of the 'Sa Huynh-Kalanay Pottery Tradition' (Solheim 1992: 201). This hypothesis developed 
following his excavations at Kalanay Cave in the Central Philippines in the early 1950s (Solheim 1957, 1959a, 1959b) where he found pottery forms and decoration closely resembling those recovered from Sa Huynh cultural sites in Central Vietnam (Solheim 1964, 1967). Thus, the external affinities of the Iron Age Sa Huynh culture should predominantly lie with the Central Philippines, according to Solheim's framework, rather than with Borneo or Peninsular Malaysia as proposed by Bellwood.

Since the end of the Vietnam War in 1975, a series of excavations have revealed more Sa Huynh culture sites, and the new findings have generated a more comprehensive framework for defining the Sa Huynh. Nonetheless, many researchers still tend to classify the pottery unearthed from any Iron Age site in Central and Southern Vietnam as 'Sa Huynh', despite considerable interregional dissimilarities. Given this variation, we need to refer to the 'Sa Huynh' culture more definitively in a typological sense to explore the internal and external connections of Iron Age Central Vietnam with surrounding areas in Southeast Asia.

The purpose of this paper is to review the Austronesian hypotheses as they relate to human movements across the South China Sea based on recent archaeological and anthropological discoveries from Iron Age sites in Central Vietnam. In particular, we challenge Solheim's scenario of the 'Sa Huynh-Kalanay Pottery Tradition' through comparative analysis of the two ceramic vessel types, and through our investigations of the jar burials from the site of Hoa Diem in Vietnam. The cultural and skeletal remains recovered from this Iron Age site help to refine the parameters of what is correctly assigned to 'Sa Huynh'.

\section{What is the 'Sa Huynh' culture?}

\section{'Pre-Sa Huynh' period}

Jar burials are the most diagnostic mortuary custom practised by societies belonging to the Sa Huynh culture during the Iron Age in Central Vietnam. Two 'pre-Sa Huynh' phases are recognised in Vietnamese archaeology: the Long Thanh and Binh Chau phases. The assemblages from these two phases are thought to be related ancestrally to the Sa Huynh culture (Chu and Dao 1978; Vu 1991; Ha 1999).

The site yielding the oldest jar burials found to date in Vietnam is Long Thanh, the late Neolithic cemetery situated near the Sa Huynh site. The site is located on a sand bank facing the South China Sea. In total, 15 jar burials and one pit burial with associated burial offerings were first uncovered during excavations in 1976 and 1978 (Chu and Dao 1978). The burials were associated with stone earrings with slits or four projections, bamboo-like shaped beads, and vessels with ringed feet. Radiocarbon determinations using charcoal indicate dates of $3370 \pm 40$ or $3752-3599 / 3587-3533$ cal. BP (86.8 per cent/8.6 per cent; Bln-1972) and $2875 \pm 60$ or 32272902 cal. BP (95.4 per cent; Bln-2096; all dates herein are calibrated using OxCal 4.2 IntCal.13 (Bronk Ramsey 2014)). Another pre-Sa Huynh site is Binh Chau, located on a sand dune near the mouth of the Tra Khuc River in Quang Ngai Province that was discovered after Long Thanh. Excavation in 1978 uncovered seven pit burials associated with pottery vessels, C-shaped clay earrings, and bronze implements (Ngo 1980). Another site thought to belong to the Binh Chau phase is Xom Oc, located on Ly Son Island about $30 \mathrm{~km}$ northeast of the Tra Khuc River mouth, and excavated in 1997. Jar and pit burials were uncovered, associated with pottery vessels, shells, shell beads, and a bronze arrowhead (Pham 2000). The Binh Chau phase is generally regarded in Vietnamese archaeology as the immediate ancestor of the Sa Huynh culture. 
Pre-Sa Huynh sites have been discovered in the highlands as well. Lung Leng, located in Kon Tum Province in the western highlands of Central Vietnam, was intensively excavated in 1999 and 2001. A total excavated area of $15,000 \mathrm{~m}^{2}$ yielded 205 jar burials, some of which belong to the Neolithic period (V.L. Bui 2005). This evidence at Lung Leng led some Vietnamese archaeologists to suspect that the jar-burial tradition had originated in the highlands and then extended eastward to the coastal areas. It assimilated aspects of the existing local cultures and developed into the Long Thanh phase, and eventually the Sa Huynh culture (Ha 1999; K.S. Nguyen 2005, 2010).

Vietnamese archaeologists have thus ascribed the ultimate ancestors of the Sa Huynh culture to several local cultures of the pre-Metal period such as Xom Con, a shell midden located along Cam Ranh Bay in Khanh Hoa Province. This site has been regarded as typical of the first 'preSa Huynh' phase, dating back to the latter half of the fourth millennium BP (C.B. Nguyen et al. 1993; Ha 1999; Lam 2011). However, the ultimate origins of the Sa Huynh culture and its mortuary customs remain unresolved.

\section{Defining the Sa Huynh culture}

The first Sa Huynh culture site was identified in 1909, when a French customs officer, Vinet, discovered several jar burials with some artefacts on the sand dune of Long Thanh. The Sa Huynh Site was excavated in 1923 by Labarre, and the findings were reported by Henri Parmentier (1925). During the 1930s, two notable archaeologists, Madeleine Colani and Olov Janse, conducted excavations on the same sand dune as Sa Huynh and Long Thanh, respectively (Colani 1937; Janse 1941). After the 1930s, the Sa Huynh sites received little attention from archaeologists due to World War II. It was only in the 1950s with Malleret and Solheim's investigations into the Sa Huynh culture that research was revived (Malleret 1959; Solheim 1959a, 1959b, 1959c). During the 1960s and early 1970s, French and Vietnamese archaeologists clarified the existence of jar burials along the Dong Nai River valley (Saurin 1973; Fontaine 1972; Fontaine and T.T. Hoang 1975). The Dong Nai discoveries extended the known geographic distribution of Sa Huynh culture sites south into Southeastern Vietnam.

Since the end of the Vietnam War in 1975, a large number of Sa Huynh sites have been discovered and excavated in Central Vietnam. These include Tam My, Phu Hoa, Bau Tram, Dai Lanh, Que Loc, Tabhing, Go Ma Voi, Lai Nghi, Hau Xa, An Bang, Go Dua, Binh Yen, Thach Bich, and Tien Lanh in Quang Nam (So Van Hoa Thong Tin Quang Nam - Da Nang 1985; Lam 1998, 2009; Lam et al. 2001; Reinecke et al. 2002; C.T. Nguyen et al. 2004; C.H. Bui and Yamagata 2004); Long Thanh, Binh Chau, Xom Oc, and Go Que in Quang Ngai (Chu and Dao 1978; Ngo1980; Pham 2000; Doan 2002, 2012); Dong Cuom in Binh Dinh (Dinh 2002; Pham 2014); and Con Rang and Con Dai in Thua Thien Hue (V.L. Bui et al. 2008). Furthermore, archaeological sites with numerous jar burials were also excavated in the southeastern part of Vietnam, represented by Giong Ca Vo and Giong Phet in the Can Gio District, Ho Chi Minh City (Dang and Vu 1997; Dang et al. 1998). Results of these excavations shed significant light on the Sa Huynh culture, drawing special attention to the diagnostic mortuary customs using burial jars and associated funerary goods.

Typical burial vessels of the Sa Huynh culture consist of cylindrical or egg-shaped jars with hat-shaped lids (Figure 19.2), buried vertically in the ground with grave goods. In addition to burial jars and lids, pottery vessels of the Sa Huynh culture include small jars, deep jars and shallow bowls (all of which may have pedestals), jars with wide or constricted necks, bowls, and so-called lamps (Yamagata 2009). Decorations also vary, including cord-marked impressions, incised triangular or rectangular designs filled with diagonal incised lines, paired incised lines interspersed with punctuations, coloured bands bound with paired incised lines, and horizontal V 
or triangular motifs of impressions made by the crenulated edge of a seashell (T.Q. Hoang 2010; Ishii 2010; Yamagata 2010). These crenulated impressions are most common among pottery of the Sa Huynh culture. These characteristic forms and decorations of Sa Huynh pottery were first presented by Parmentier (1925).

The Sa Huynh culture in the Thu Bon River valley in Quang Nam may be divided into two phases, provisionally labelled I and II by the author (MY) (Yamagata 2006, 2009, 2010). Representative sites for Phase I include Binh Yen H1 (excavation pit No. 1), Thach Binh and Go Ma Voi, while representative sites for Phase II include Binh Yen H2 and Go Dua. The differences between Phase I and II include the type of burial jars (I: egg-shaped, II: cylindrical), form and decoration of pottery (I: diverse, II: less diverse), number and type of metal objects (I: more bronze implements, II: more iron implements with a few bronze bowls and mirrors), and number of beads (increasing in II).

The Sa Huynh culture declined during the first century $\mathrm{AD}$, and soon afterwards, probably in the early second century AD, the Tra Kieu and Go Cam sites were settled (K.D. Nguyen 2005; Yamagata 2007b, 2011). Neither is a burial site of the Sa Huynh culture, and Tra Kieu is generally identified as the capital of the early polity of Linyi (Champa). The indigenous society associated with the Sa Huynh culture must have been involved in the prosperous Nanhai trade connecting India and China, but at the same time was confronted by the southward expansion of the Han (Yamagata 2007b). Some jar burials of the final Phase II at the Binh Yen, Go Dua and Lai Nghi sites contained Western Han bronze mirrors (Yamagata et al. 2001).

Based on the burial jars and lids produced locally, a cylindrical or egg-shaped jar often associated with a hat-shaped lid is the most specific material for defining the Sa Huynh culture, as proposed elsewhere (Yamagata 2007a, 2010, 2013; Suzuki 2011). Given this definition, the range of the Sa Huynh culture extended from Hue in the north, in a southerly direction to Nha Trang as far as the coastal regions of Central Vietnam (Yamagata 2011, 2013; Figure 19.1).

This geographically restricted perspective on the Sa Huynh cultural sphere is shared by only a few Vietnamese archaeologists (e.g. C.H. Bui 2009). Most would also include Iron Age sites associated with jar burials in Dong Nai and Ho Chi Minh City (Ha 1983; Vu 1991; Lam 2011). Dividing Sa Huynh spatially into closely associated Northern and Southern Sa Huynh cultures has been proposed by Lam (2011).

\section{Pottery vessels of the Sa Huynh culture}

Considering the large sample of Sa Huynh pottery vessels, we are now in a position to critique earlier uses of the concept of 'Sa Huynh'. For instance, pottery locally referred to as 'binh kieu Sa Huynh' (Sa Huynh-type vase) unearthed from Giong Ca Vo in Ho Chi Minh City (Dang et al. 1998: 163) displays a quite distinct shape. These pottery vessels have an everted rim, constricted neck, sharply angled body, and a short ring-foot. Although the excavators designate vessels characterised by these specific features as 'Sa Huynh type', such characteristics are in fact rarely seen among pottery of the Sa Huynh culture in Central Vietnam. Concerning curvilinear or rectangular scrolls and triangles decorated on 'binh kieu Sa Huynh', some vessels of the Sa Huynh culture also bear those patterns, but only a small proportion. In the opinion of the author (MY), for the purposes of defining Sa Huynh pottery, more attention should be given to the noi (in Vietnamese) forms and associated decorations that constitute the modal expression, rather than assuming Sa Huynh affiliation through incidental similarities. 

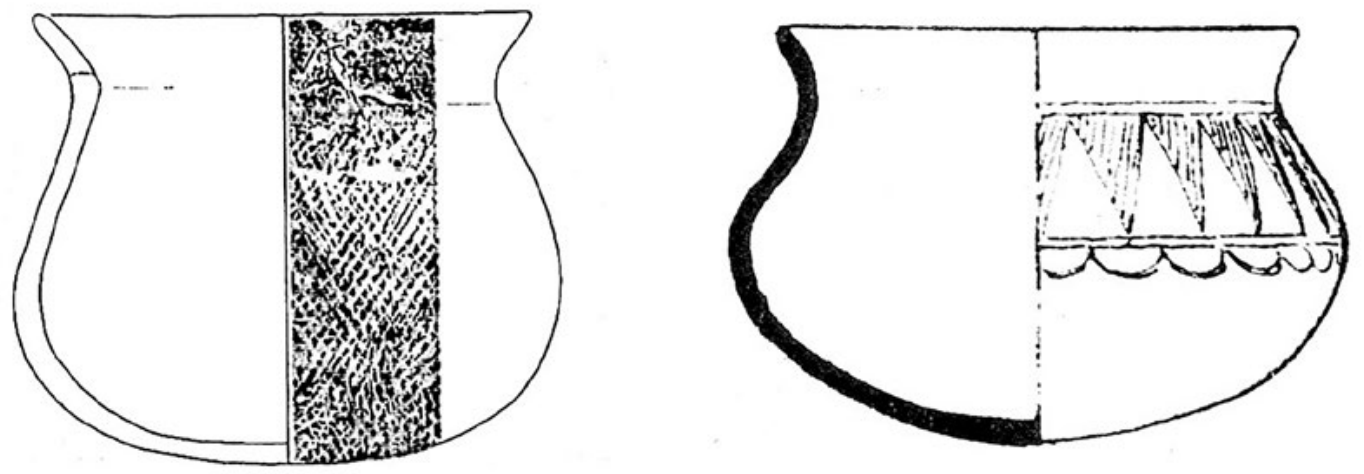

Figure 19.3 Sa Huynh pottery locally called 'noi', found at the Sa Huynh and Thach Bich sites; (right) height: $11.0 \mathrm{~cm}$; (left) height: $12.5 \mathrm{~cm}$.

Source: (right) Parmentier 1925; (left) drawing by M. Yamagata.

The strong presence of noi, a Vietnamese term for a jar with a wide or constricted neck (Figure 19.3) can be illustrated by the following examples. From Phase I of the Go Ma Voi site, mentioned above, 86 (40 per cent) of the 215 pottery vessels are noi, whilst another 35 (16 per cent) pottery forms are shallow bowls with pedestals commonly known as mam bong or bat bong (Reinecke et al. 2002). Of the 125 vessels from four sites in Hoi An, 68 (54.4 per cent) were identified as noi and 30 (24.0 per cent) as bat bong (Tran et al. 2004). Likewise, at Con Rang in Hue, 354 funerary accessory pottery vessels were uncovered, 115 (32.5per cent) of which were noi, and 89 (25.1 per cent) are binh, jars with pedestals (V.L. Bui et al. 2008). Although these figures are open to influence by the criteria used to classify the pottery at each site, the modal category of Sa Huynh pottery is definitely noi (Ishii 2010; Yamagata 2013). Various decorations such as cord-marked impressions, impressions of a shell edge forming triangles, horizontal $\mathrm{V}$ or semi-circular patterns, incised triangular or rectangular designs with diagonal incised lines, paired incised lines interspersed with punctuations, and coloured bands bound with paired incised lines are commonly displayed on Sa Huynh noi pottery.

The pottery of Phase II, the final stage (first century BC to the first century AD) of the Sa Huynh culture in Quang Nam, shows differences in form and decoration. At the Binh Yen site H2 trench, 35 vessels were associated with seven jar burials: 21 were bowls and shallow bowls, six were small jars, and just six could be classified as noi. Cord-marked impressions predominate, and red and black colouring is applied to some vessels. Only two jars with foot stands bear simple incised triangles (C.H. Bui and Yamagata 2004; Yamagata 2006).

In characterising the pottery of the Sa Huynh culture, the modal category of noi should be emphasised, instead of regarding vessel forms that are more decorative and distinctive but fewer in number as representative of this culture.

\section{Sa Huynh and Kalanay: Solheim's idea revised}

Solheim's ponderings on the 'Sa Huynh-Kalanay Pottery Tradition' led his thinking towards a hypothesis of extensive maritime networks established by boat traders named the Nusantao Maritime Trading and Communication Networks (Solheim 1984-1985, 2006). This scenario includes four lobes of trade and communication covering a very broad area and timeframe. The Northern Lobe extended across Taiwan, Fujian, and coastal China northward to coastal Korea and the Japanese archipelago. The Eastern Lobe extended from the Moluccas in Eastern Indonesia, to the Bismarcks in Northwestern Melanesia, and across the Pacific to Easter Island. 
The Western Lobe encompassed Malaysia and Western Indonesia, Sri Lanka, India and the far eastern coast of Africa, including Madagascar. The Central Lobe included eastern coastal areas of Vietnam, Southern China, and the Philippines. The Nusantao traders originated in Wallacea around 12,000 BP and developed a Pre-Austronesian language for trade communication. The network of the late Central Lobe then formed with the development of the Austronesian language, the traders' lingua franca, before 7000 BP.

In the scenario of Solheim's trading networks, the 'Sa Huynh-Kalanay Pottery Tradition' extended from eastern coastal Mainland Southeast Asia to insular Southeast Asia between approximately $2500 \mathrm{BP}$ and $1000 \mathrm{BP}$. Solheim hypothesised that the origin and spread of the 'Sa Huynh-Kalanay Pottery Tradition' was through the agency of the Nusantao boat trading people, although not all of them made or used pottery of that tradition (Solheim 2002).

Based on his analysis of the pottery found in Kalanay Cave, which he excavated in 1951 and 1953, and of other collections in the Central Philippines, Solheim (1957, 1959b, 2002) proposed recognition of the 'Kalanay Pottery Complex' for a group of related pottery styles. In his comparison of the Kalanay Pottery Complex with the ceramic assemblage of the Sa Huynh site reported by Parmentier (1925), he concluded that a close similarity between the two ceramic traditions existed. Furthermore, he found a close cultural affiliation among local pottery complexes widely distributed throughout Island Southeast Asia (e.g. Niah Great Cave in Western Borneo and Gua Cha in Peninsular Malaysia). His observation of these pottery complexes led him to hypothesise that they were all part of a single pottery tradition that arrived at widespread locations through trading and movement of people (Solheim 1959c: 186). The concept of the Kalanay Pottery Complex thus developed into the notion of the 'Sa Huynh-Kalanay Pottery Tradition' made up of pottery complexes related to each other.

Solheim defined the following motifs as most specific in the Kalanay Pottery Complex (Solheim 2002):

1. Paired diagonals and borders.

2. Curvilinear scrolls and triangles.

3. Rectangular scrolls and triangles.

4. Emphasised punctuation field or dashes separated by incised lines.

5. Crenulations impressed with a shell edge.

6. Impressed or carved 'scallop' design.

7. Carved cutouts in ring stands.

More recent studies have shown that among these, decorations 2, 4, 5 and 7 are present on Sa Huynh pottery vessels, whilst the others are rarely seen or absent. In particular, decoration 6, which Solheim considers to be most diagnostic of the Kalanay Pottery Complex, is absent amongst Sa Huynh pottery. In addition, the Kalanay Pottery Complex lacks any cord-mark impressions that frequently appeared on Sa Huynh vessels.

The incised rectangular scrolls (motif 3) are occasionally seen on burial lids of the Sa Huynh culture, but in fact appear infrequently on funerary accessory pottery. Also, the nominal similarity between Sa Huynh and Kalanay pottery on their crenulated impressions made with a shell edge (motif 5) need not reflect true correspondence. These are very common on Sa Huynh but the actual shell-impressed decorations are different from those of the Kalanay Pottery Complex. 
Thus, dissimilarities in pottery style and decoration show that Sa Huynh is not related to the Kalanay Pottery Complex. Instead, and importantly, there is remarkable similarity between Kalanay pottery and the pottery from another site called Hoa Diem in Central Vietnam that has a cultural assemblage that is not assigned to Sa Huynh.

\section{Hoa Diem: Jar burials left by immigrants from the Philippines?}

The Hoa Diem site is situated on the floodplain around Cam Ranh Bay, within the administrative district of Cam Ranh city, Khanh Hoa Province in Central Vietnam (Figure 19.1). The site is only about $400 \mathrm{~m}$ from the coastline. It was discovered during a reconnaissance survey by the Vietnam Institute of Archaeology in 1998, which then undertook excavations in 1999 and 2002 with the Khanh Hoa Provincial Museum (V.L. Bui et al. 2005).

What especially interested the author (MY) and her Vietnamese colleagues Bui Chi Hoang and Nguyen Kim Dung was the spherical type of burial jars used at Hoa Diem (Figure 19.4). These are distinct from cylindrical or egg-shaped burial jars commonly used within the Sa Huynh culture. Moreover, funerary accessory pottery vessels found at Hoa Diem differ significantly from those found with Sa Huynh jar burials, despite Hoa Diem's locality adjacent to the distribution area of the Sa Huynh culture. Most notable is the striking similarities of the pottery from Hoa Diem with the pottery at Kalanay Cave, Masbate Island in the Central Philippines, excavated by Solheim (1957, 1959a, 1959b) (Figure 19.5). Just as intriguingly, similar vessels are reported by Solheim (1964) to have been found on Ko Din Island near Ko Samui, Southern Thailand. Thus, Hoa Diem may be regarded as a potential site for convincing evidence supporting human movements across the South China Sea during the Iron Age.

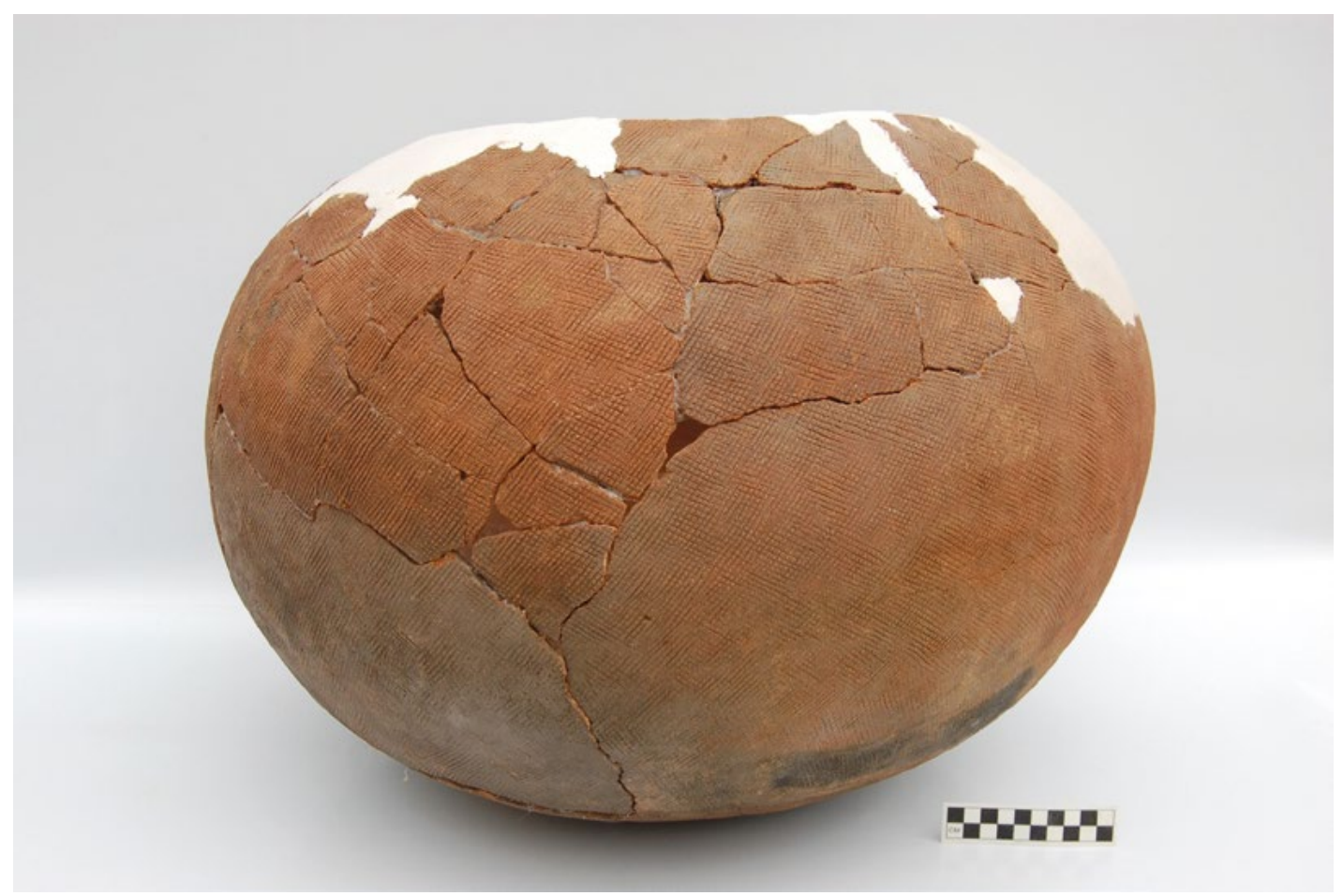

Figure 19.4 A spherical burial jar uncovered from the site of Hoa Diem (Burial No. 07HDH1M6, max diameter: $55-59 \mathrm{~cm}$; height: $42.6 \mathrm{~cm}$ ).

Source: M. Yamagata. 


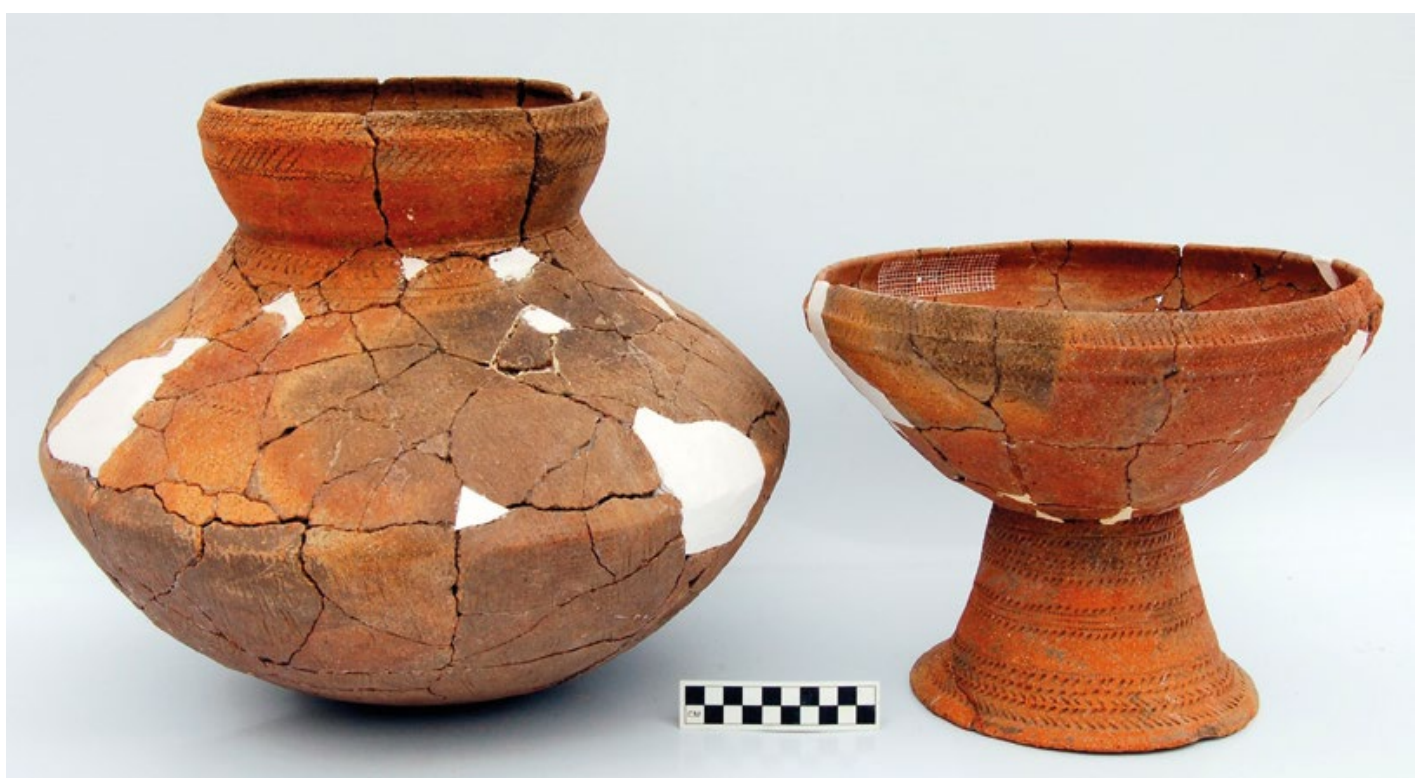

Figure 19.5 Burial jars (left) and lid (right, a pedestal vessel laid upside down upon the jar) decorated with the impression of a shell edge uncovered from Hoa Diem (Burial No. 07HDH1M14, height of jar: $27.1 \mathrm{~cm}$; height of lid: $23.5 \mathrm{~cm}$ ).

Source: M. Yamagata.
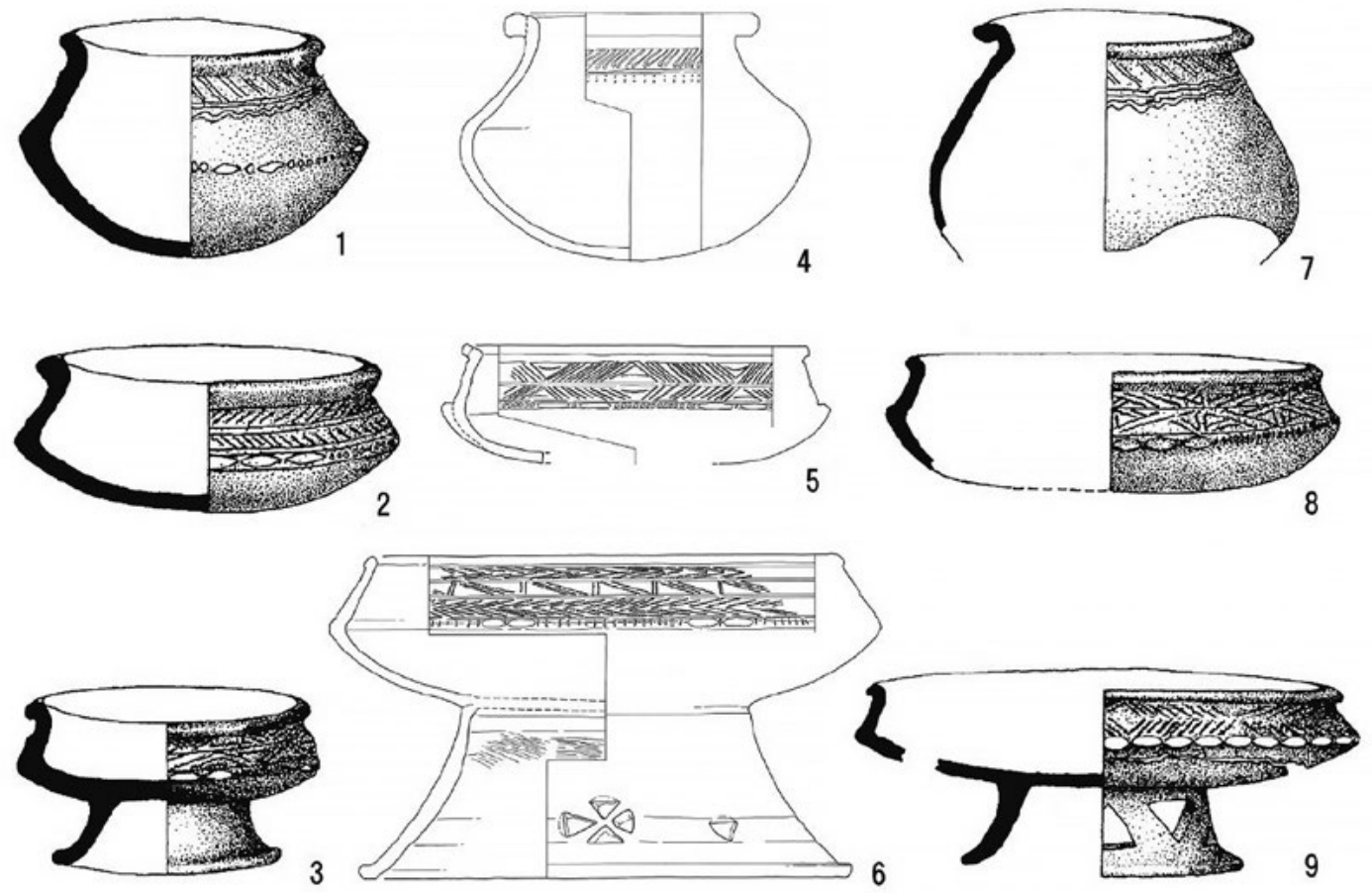

Figure 19.6 Pottery from Kalanay (7-9), Hoa Diem (4-6), Samui (1-3). Rim diameter: $4.10 .2 \mathrm{~cm}$; 5. $15.0 \mathrm{~cm} ; 6.20 .2 \mathrm{~cm}$. Size unknown; 1-3, 7-9.

Sources: 1-3, 7-9 adapted from Solheim (1992), reproduced with the permission of White Lotus Press; 4-6 adapted from Yamagata et al. (2013), reproduced with the permission of Showa Women's University Institute of International Culture. 
To undertake a more extensive investigation of Hoa Diem, especially regarding pottery and human remains, an international team of Vietnamese and Japanese archaeologists and physical anthropologists from the Southern Institute of Social Sciences, Vietnam Institute of Archaeology, Khanh Hoa Provincial Museum, and Japan conducted excavations in 2007 and 2010 (C.H. Bui et al. 2010; Yamagata et al. 2013). In 2007, a pit covering $48 \mathrm{~m}^{2}$ produced 21 skeletons from 13 jar burials and two extended burials. In 2010, a further six individuals from five jar burials were recovered from a total $21 \mathrm{~m}^{2}$ of excavation, and four more jar burials were identified in two test pits of a total of $15 \mathrm{~m}^{2}$. All these excavation trenches were located within the area of the site known as Hoa Diem 1. Approximately $200 \mathrm{~m}$ to the southeast of Hoa Diem 1, two extended inhumations were found in a small test pit at Hoa Diem 2 (Yamagata et al. 2013). Besides this international project, in 2011 the National Museum of Vietnamese History conducted another excavation at Hoa Diem 1, covering an area of $51.5 \mathrm{~m}^{2}$ that yielded another 26 jar burials (Le and Dinh 2013).

At Hoa Diem, most burial jars have spherical bodies (Figure 19.4). As well, one burial jar has an incised and impressed pattern on its body and rim, associated with a knobbed lid and painted patterns. Another two burial jars were decorated with impressions made with the edge of a seashell, and the pedestal vessels serve as lids that also bear the same decoration (Figure 19.5). The spherical jars are similar to those of Giong Ca Vo in Ho Chi Minh City, but other types of burial jars and lids have never been encountered before. They are completely different from those found at Sa Huynh culture sites in Central Vietnam. Many mortuary accessory pottery vessels found in these new excavations again show close affinities with the Kalanay Pottery Complex in Central Philippines (Figure 19.5). These vessels include:

1. Jars with incised parallel diagonals and borders. Some of them bear impressed 'scallop' designs at an angle around the body.

2. Shallow bowls with impressions of a shell edge. Most of them bear impressed 'scallop' designs at an angle around the body.

3. Shallow bowls with ring stand, and carved cutouts.

All of these are regarded as diagnostic characteristics of the Kalanay Pottery Complex (Figure 19.7, top and middle). Apart from these remains, a jar with eight projections like breasts and nipples is also notable at Hoa Diem (Figure 19.7, bottom). This is a type of pottery decoration that has never been discovered in Vietnam before. Interestingly, similar vessels with nipples were found on Siquijor Island in the Central Philippines (Solheim 2002: Plate 15).

Moreover, other kinds of grave goods such as beads and iron tools exhibit characteristics distinctive from those of the Sa Huynh culture. The absence of the most common earring type found in Sa Huynh burials, the lingling-o, from Hoa Diem also distinguishes the two burial traditions. Given these observations, the burial assemblage of Hoa Diem shows greater affinity with those of distant Kalanay than it does with neighbouring Sa Huynh.

A typological study of the Kalanay Pottery Complex by Tanaka (1987) divides the complex into two phases: earlier and later. The Hoa Diem complex is apparently affiliated with the later phase. Furthermore, most recent surveys done by a joint French/Thai team have discovered the Kalanay-type pottery sherds at several sites along the Isthmus of Kra in Peninsula Thailand (Favereau 2015). 

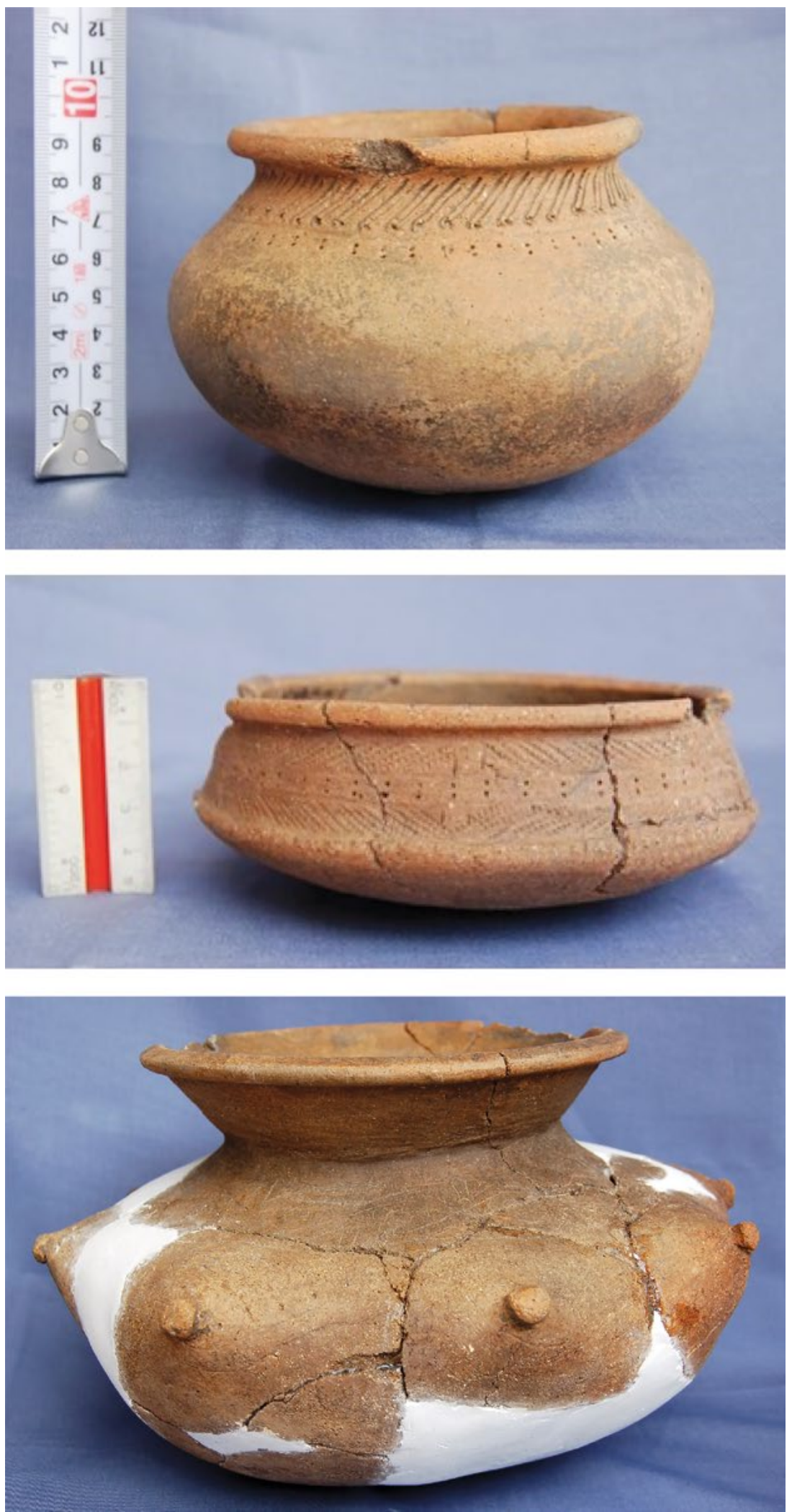

Figure 19.7 Funerary accessory pottery vessels found at Hoa Diem (top: height $9.5 \mathrm{~cm}$ with rim diameter of $9.4 \mathrm{~cm}$ (outer); middle: height $4.7 \mathrm{~cm}$ with rim diameter of $12.5 \mathrm{~cm}$; and bottom: height $15.6 \mathrm{~cm}$ with rim diameter of $15.1 \mathrm{~cm}$ ).

Source: M. Yamagata. 
Considering these material differences, two possible factors could explain the lack of cultural relationship between Hoa Diem and Sa Huynh: chronological separation; and cultural, social or perhaps ethnic differences between the two populations. Based on the comparative study of the material culture, the Hoa Diem cemetery with Kalanay-type pottery most likely dates from the second and third centuries $\mathrm{AD}$. Thus, the authors consider temporal difference to be the most parsimonious explanation for variations in the material culture exhibited by Sa Huynh and Hoa Diem (Yamagata et al. 2013: 29-30), although the two explanations mentioned above may not be mutually exclusive. The Hoa Diem cemetery with Kalanay-type pottery was possibly in use shortly after the decline of Sa Huynh. It is then during the latter/end of Sa Huynh that a clear connection finally emerged between the Iron Age populations of the Central Philippines, Central Vietnam and Southern Thailand.

\section{Origin of the Hoa Diem people: Bio-anthropological perspectives}

From all the seasons of excavation, 49 human skeletons were recorded at Hoa Diem. Although they were poorly preserved, the bioanthropological study has indicated that most burials were primary inhumations (Figure 19.8). Multiple individuals in a jar usually consisted of a single adult and one or more infants. The adult was the primary interment, but the timing for the introduction, either with the adult of after, remains unclear.

Skeletal preservation, specific observations, and morphological data including cranial and dental measurements and nonmetric dental traits were presented in the excavation report (Matsumura and Nguyen 2013). Previous work cited in this report included preliminary comparative analyses in order to identify the craniometric affinities of the Hoa Diem populations using geographically broad population samples across Southeast/Northeast Asia and the Circum-Pacific regions. The initial study broadly showed affinities between the Hoa Diem population and some groups in Island Southeast Asia.

Here we present the results of a more substantial analysis using alternative methods applied to datasets that include newly recorded samples from the Southeast Asian region. The comparative archaeological samples are listed in Table 19.1.

Figure 19.9 presents the results from the neighbor-net split analysis (software provided by Huson and Bryant 2006) applied to distances of the Q-mode correlation coefficients based on 16 cranial measurements (Martin's method number: M1, M8, M9, M17, M43[1], M43c, M45, M46b, M46c, M48, M51, M52, M54, M55, M57, M57a). The network diagram resulting from neighbor-net split analysis branches into two major clusters at the top left and bottom right. These include: (1) East Asians and many Southeast Asians ranging from Late Neolithic to modern times; and (2) Australo-Melanesians and early Holocene Southeast Asians including the Hoabinhian and Early Neolithic series.

The jar burial assemblage with Kalanay-type pottery vessels of Hoa Diem 1 dates from the second to third century $\mathrm{AD}$, corresponding with the period just after the decline of Sa Huynh culture. A $\mathrm{C}^{14}$ determination on a human tooth from a jar burial of Hoa Diem 1 produced a calibrated age $(2 \alpha)$ of $1910-1898 \mathrm{cal}$. BP (2.2 per cent) and $1877-1757 \mathrm{cal}$. BP (93.2 per cent; IAAA101437). Another $C^{14}$ determination on a human tooth from an extended burial at Hoa Diem 2 produced a calibrated age $(2 \alpha)$ of 2200-1951 cal. BP (95.4 per cent; IAAA-100714).

In the network tree depicted in Figure 19.9, Hoa Diem 1 (from the jar-burial group, Figure 19.8) was branched with the inhabitants of Taiwan (Bunun), Sumatra, and the Moluccas Islands, as well as other Southeast Asians including modern Cambodians, Laotians, Thais, Filipinos and 
Southern Chinese. Hoa Diem 2 (one of the burials in extended position, see Figure 19.8), groups with Semang Negritos, and is relatively close to the second cluster consisting of the AustraloMelanesian and Hoabinhian samples.

Previous morphometric analyses (e.g. Matsumura and Oxenham 2014) demonstrate an apparent genetic discontinuity between pre- and post-Neolithic populations. Events occurring during the Neolithic were apparently pivotal in terms of the micro-evolutionary history of Southeast Asia. The network tree diagrams in those analyses exhibit close affinities between pre-Neolithic Hoabinhian and Australo-Melanesian samples on the one hand, and a northern source for contemporary Southeast Asians on the other. This suggests that pre-Neolithic foragers descended from the first occupants of Southeast Asia, sharing common ancestry with present-day Australian Aboriginal and Melanesian people.

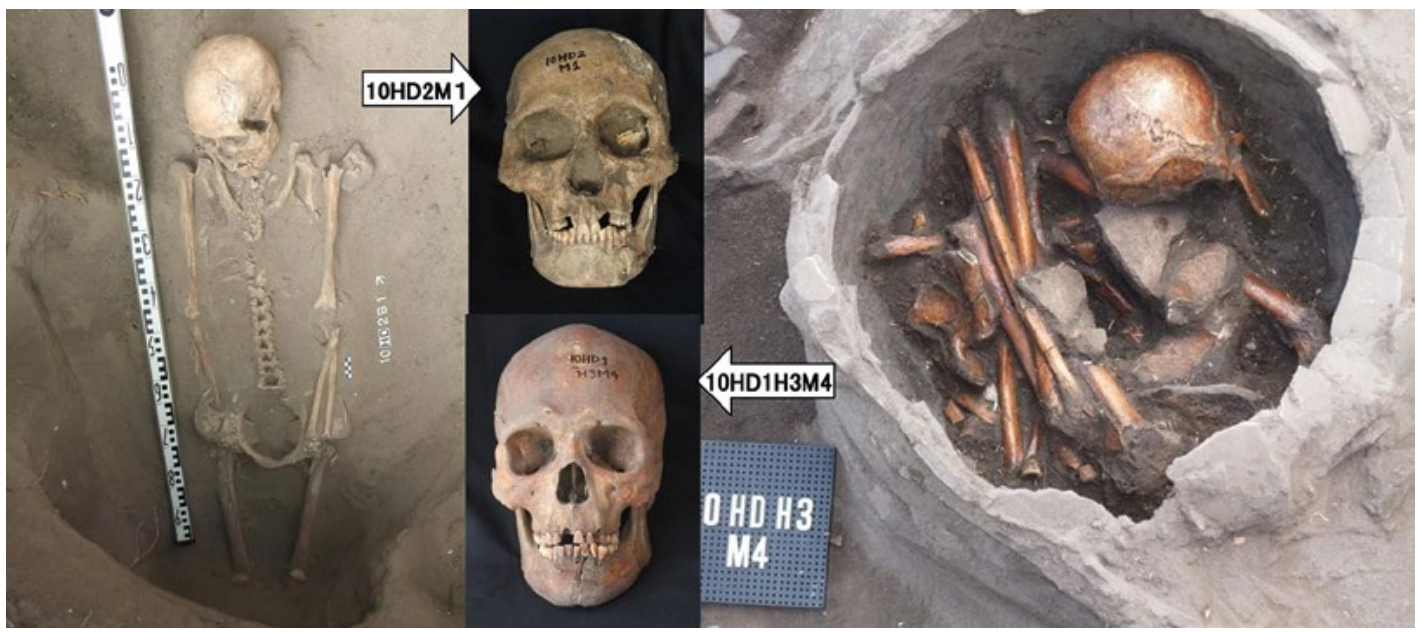

Figure 19.8 Extended burial and skull at Hoa Diem 2 (Burial No. 10HD2M1) and inhumation jar burial and skull at Hoa Diem 1 (Burial No. 10HD1H3M4).

Source: H. Matsumura.

Regarding the origin of Neolithic to post-Neolithic populations in Southeast Asia, it was widely believed they arose through a greater or lesser degree of genetic exchange between the early indigenous populations and immigrants from East Asia. Demographic transition leading to such genetic exchange was hypothetically ascribed to large-scale integration with a populationlanguage-agriculture dispersal package originating from East Asia (e.g. Bellwood, 1997, 2005; Glover and Higham 1996; Higham 1998, 2002), ultimately contributing to the post Neolithic Southeast Asian phenotype. In terms of the Austronesian-language family, as mentioned above, linguistic and archaeological considerations suggest that Taiwan was the ultimate source of these linguistic and population dispersals (Bellwood, 1997, 2005). The Taiwan émigrés intermixed with the indigenous Australo-Melanesian stock as they diffused through Southeast Asia. The human skeleton from the Hoa Diem 2 site, which was previously buried in an extended position, may still preserve genetic traits of the early indigenous population, which perhaps implies an origin from somewhere in Island Southeast Asia. Be that as it may, the closer affinity of later jar-burial people (Hoa Diem 1) to insular Southeast Asian groups suggests an Iron Age colonisation from the Philippines across the South China Sea. 
Table 19.1 Comparative population samples prehistoric of prehistoric date.

\begin{tabular}{|c|c|c|c|}
\hline Sample & Locality & Period & Remarks \\
\hline \multicolumn{4}{|c|}{$\star$ Pre-Neolithic Samples } \\
\hline Liujinag & China & Late Pleistocene & Individual, Site in Guangxi Prov. \\
\hline Lang Gao & Vietnam & Hoabinhian & $\begin{array}{l}\text { Averages of two individuals (nos } 17 \text { and 19), Site in Hoa Binh } \\
\text { Prov., N Vietnam (Cuong 2007) }\end{array}$ \\
\hline Lang Bon & Vietnam & Hoabinhian (ca. 7000 BP) & Individual, Site in Thanh Hoa Prov., N Vietnam (Cuong 2007) \\
\hline Mai Da Nuoc & Vietnam & Hoabinhian (ca. 8000 BP) & Individual, in Thanh Hoa Prov., N Vietnam (Cuong 1986, 2007) \\
\hline $\begin{array}{l}\text { Hoabinhian } \\
\text { (average) }\end{array}$ & Vietnam & $\begin{array}{l}\text { Hoabinhian (ca. 11000-8000 } \\
\text { BP) }\end{array}$ & $\begin{array}{l}6 \text { specimens including fragmental remains from above } 4 \text { sites } \\
\text { and } 1 \text { from Mai Da Dieu site in Thanh Hoa Prov. (Cuong 2007) }\end{array}$ \\
\hline Bac Son & Vietnam & $\begin{array}{l}\text { Epi-Hoabinhian (ca. 8000- } \\
7000 \text { BP) }\end{array}$ & $\begin{array}{l}\text { Sites of Pho Binh Gia, Cua Git, Lang Cuom, and Dong Thuoc } \\
\text { in N Vietnam (Mansuy and Colani 1925) }\end{array}$ \\
\hline Con Co Ngua & Vietnam & $\begin{array}{l}\text { Da But Culture (ca. } 6000 \\
\text { BP) }\end{array}$ & Site in Than Hoa Prov., N Vietnam \\
\hline Gua Cha & Malaysia & $\begin{array}{l}\text { Hoabinhian (ca. 8000-6000 } \\
\text { BP) }\end{array}$ & $\begin{array}{l}\text { Individual Sample No. H12, Site in Kelantan Prov. } \\
\text { (Sieveking 1954) }\end{array}$ \\
\hline Tam Hang & Laos & Early Holocene & $\begin{array}{l}\text { Hua Pan Province, N Laos (Mansuy and Colani 1925; } \\
\text { Huard and. Saurin 1938; Demeter et al. 2009) }\end{array}$ \\
\hline Zengpiyan & China & Mesolithic (ca. 8000 BP) & Site in Guangxi Prov. (IACAS et al. 2003) \\
\hline \multicolumn{4}{|c|}{$\diamond$ Neolithic Samples } \\
\hline Man Bac & Vietnam & $\begin{array}{l}\text { Late Neolithic (ca. } \\
\text { 3800-3500 BP) }\end{array}$ & Site in Ninh Binh Prov., N Vietnam (0xenham et al. 2011) \\
\hline An Son & Vietnam & Late Neolithic (ca. 3800 BP) & $\begin{array}{l}\text { Site in Long An Prov., S Vietnam (Nishimura and Dung 2002; } \\
\text { Cuong 2006; Bellwood et al. 2013) }\end{array}$ \\
\hline Ban Chiang & Thailand & $\begin{array}{l}\text { Neolithic-Bronze Age } \\
\text { (ca. 3500-1800 BP) }\end{array}$ & $\begin{array}{l}\text { Site in Udon Thani Prov. (Gorman and Charoenwongsa 1976; } \\
\text { Pietrusewsky and Douglas 2002) }\end{array}$ \\
\hline Non Nok Tha & Thailand & $\begin{array}{l}\text { Neolithic-Bronze Age } \\
\text { (ca. 3500-3000 BP) }\end{array}$ & Site in Khok Kaen Prov. (Bayard 1971) \\
\hline Weidun & China & $\begin{array}{l}\text { Neolithic (ca. } 7000-5000 \text { BP, } \\
\text { Majiabang Culture) }\end{array}$ & Sites in Jiangsu Prov. Central China (Nakahashi and Li 2002) \\
\hline Baikal & Russia & $\begin{array}{l}\text { Neolithic (ca. 8000-4000 } \\
\text { BP) }\end{array}$ & Lake Baikal (Debets 1951) \\
\hline Jomon & Japan & Neolithic (ca. 5000-2300 BP) & Over almost the entire Japanese archipelago \\
\hline \multicolumn{4}{|c|}{ Bronze-Iron Age Samples } \\
\hline Anyang & China & $\begin{array}{l}\text { Yin (Shan) Period (ca. 3500- } \\
3027 \text { BP) }\end{array}$ & Site in Henan Prov. Central China (IHIA and CASS 1982) \\
\hline Giong Ca Vo & Vietnam & Iron Age (ca. 2300-2000 BP) & Site in Ho Chi Minh (Dang and Vu 1997) \\
\hline Go 0 Chua & Vietnam & Iron Age (ca. 2300-2000 BP) & $\begin{array}{l}\text { Site in Long An Prov., S Vietnam (Francken and Wahl 2010; } \\
\text { Cuong in press) }\end{array}$ \\
\hline Hoa Diem & Vietnam & $\begin{array}{l}\text { Iron Age (Hoa Diem 2=ca. } \\
150 \text { BP; Hoa Diem 1=ca. } \\
\text { 2000-1700 BP) }\end{array}$ & $\begin{array}{l}\text { Site of Hoa Diem in Khanh Hoa Prov., Central Vietnam } \\
\text { (Yamagata et al. 2013) }\end{array}$ \\
\hline Dong Son & Vietnam & $\begin{array}{l}\text { Dong Son Period (ca. 3000- } \\
1700 \text { BP) }\end{array}$ & Sites of Dong Son Culture in N Vietnam (Cuong 1996) \\
\hline Phum Snay & Cambodia & Iron Age (ca. 2350-1800 BP) & Site in Preah Neat Orey District, W Cambodia \\
\hline Yayoi & Japan & $\begin{array}{l}\text { Yayoi Period (ca. 2800-1700 } \\
\text { BP) }\end{array}$ & $\begin{array}{l}\text { Sites of Doigahama, Nakanohama, Kanenokuma and others } \\
\text { in Northern Kyushu and Yamaguchi Districts, W Japan }\end{array}$ \\
\hline
\end{tabular}

Source: H. Matsumura. 


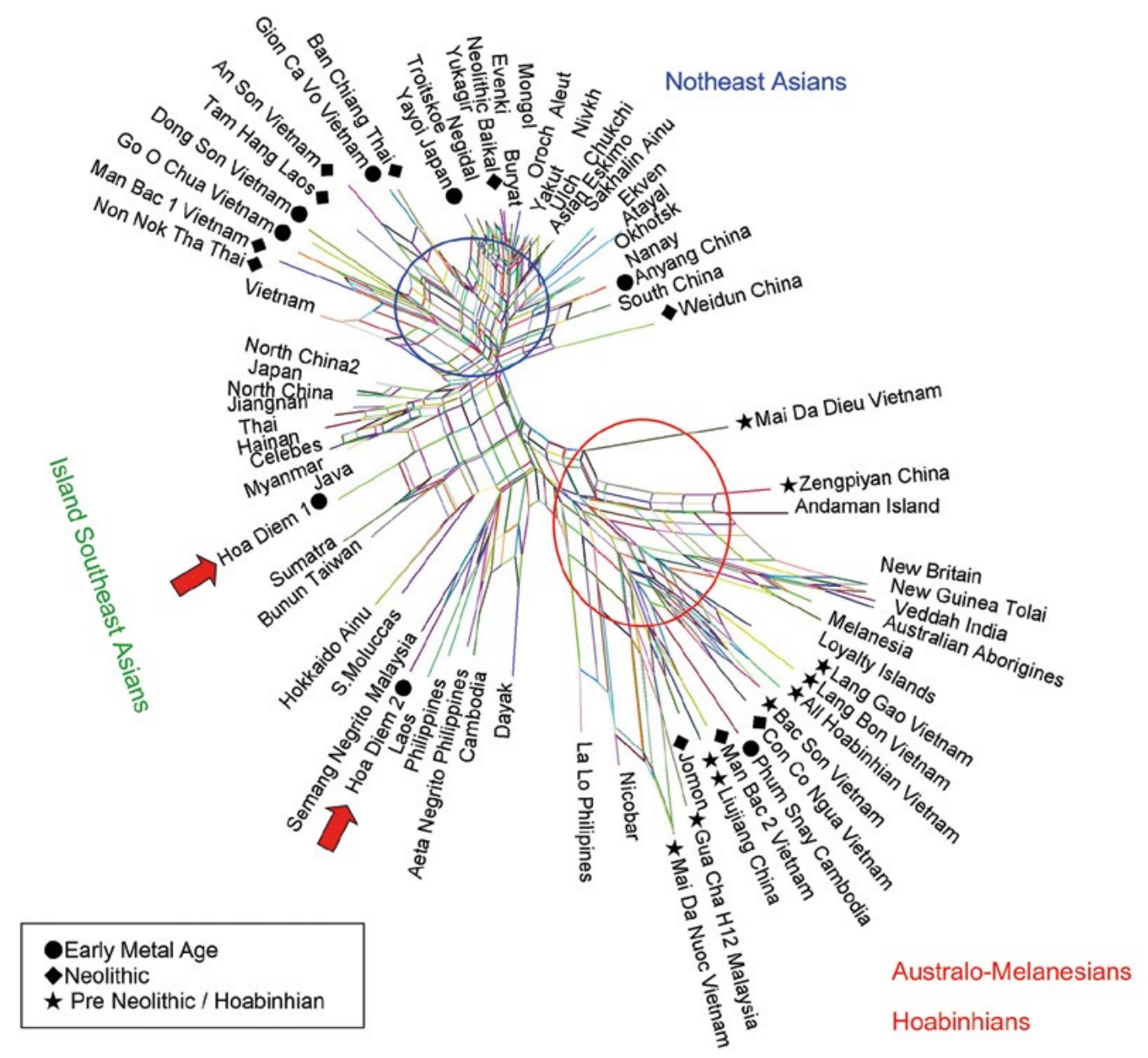

Figure 19.9 Neighbor-net tree based on 16 craniometric data sets (symbols: see Table 19.1).

Source: H. Matsumura.

\section{Conclusions}

This paper reassessed the definition of the 'Sa Huynh' culture that is currently unclear due to the considerable variation displayed in cultural assemblages by locality. It has refined the definition of what should be considered as part of the 'Sa Huynh' cultural repertoire in response to the continuing ambiguity in the spatial, temporal and material culture parameters of the tradition. The most specific and typical characteristic of the Sa Huynh culture is its mortuary practice using cylindrical or egg-shaped burial jars associated with hat-shaped lids. If adopted, this basic definition of the special distribution of Sa Huynh should be restricted to the geographic region across Central Vietnam between Hue City in the north and Nha Trang City in the south. The Sa Huynh culture emerged in the fourth or third century BC and declined at the end of the first century AD. Tra Kieu, the ancient capital of Linyi (Champa) subsequently emerged in the second century AD.

Solheim proposed a 'Sa Huynh-Kalanay Pottery Tradition' in his extensive hypothesis of the Nusantao Maritime Trade and Communication Networks. However, our study demonstrates substantial dissimilarity between the Sa Huynh and Kalanay pottery assemblages. On the other hand, our excavations of the Hoa Diem site in Khanh Hoa Province, Central Vietnam, unearthed 
large numbers of burial jars and funeral pottery vessels that are strikingly similar to pottery from Kalanay in the Philippines and Samui Island in Thailand - all of which is quite different from Sa Huynh pottery. The date of jar burials with Kalanay type pottery at Hoa Diem is estimated to be in the second and third centuries AD (Iron Age) and thus postdates the Sa Huynh culture. Bio-anthropological analysis using craniometric data also suggests a close affinity of the jarburial people at Hoa Diem to insular Southeast Asians, including populations from Taiwan, Sumatra, Java and the Philippines. This finding confirms the view that the Hoa Diem site marks a colonisation of Austronesian speakers, who migrated from somewhere in ISEA across the South China Sea and settled in Central Vietnam during the Iron Age.

\section{Acknowledgements}

In this paper Vietnamese diacritics are omitted from the main text, but included in the references.

We express our sincere gratitude toward Bui Chi Hoang from the Southern Institute of Social Sciences in Vietnam; Nguyen Kim Dung and Nguyen Lan Cuong from the Vietnam Institute of Archaeology; Ian C. Glover from the Institute of Archaeology, University College London; and the staff at the Quang Nam Provincial Museum and Khanh Hoa Provincial Museum for their collaborations and providing great support to our research project in Vietnam. Acknowledgements for comparative population samples used in anthropological analyses are presented elsewhere (Matsumura and Oxenham 2014).

This study was supported in part by Japanese Society for the Promotion of Science (JSPS) KAKENHI Grant no. 18520593 , no. 20520666 and no. 23247040.

\section{References}

Bayard, D.T. 1971. Non Nok Tha: The 1968 Excavation, procedure, stratigraphy, and summary of the evidence. University of Otago Studies in Prehistoric Anthropology, vol. 4. Dunedin: University of Otago.

Bellwood, P. 1997. Prehistory of the Indo-Malaysian Archipelago. 2nd edition. Honolulu: University of Hawaii Press.

- 2004. The origins and dispersals of agricultural communities in Southeast Asia. In I. Glover and P. Bellwood (eds), Southeast Asia from Prehistory to History, pp. 21-40. Oxford and New York: RoutledgeCurzon.

—. 2005. First Farmers: The Origins of Agricultural Societies. Malden, Oxford and Victoria: Blackwell.

Bellwood, P. and I. Glover. 2004. Southeast Asia: Foundations for an archaeological history. In I. Glover and P. Bellwood (eds), Southeast Asia from prehistory to history, pp. 4-20. Oxford and New York: RoutledgeCurzon.

Bellwood, P. and E. Dizon. 2005. The Batanes archaeological project and the 'Out of Taiwan' hypothesis for Austronesian dispersal. Journal of Austronesian Studies 1(1): 1-33.

- 2008. Austronesian cultural origins: Out of Taiwan, via Batanes Islands, and onwards to Western Polynesia. In A. Sanchez-Mazas, R. Blench, M. Ross, I. Peiros and M. Lin (eds), Past Human Migrations in East Asia, pp. 23-39. Oxford and New York: RoutledgeCurzon.

- 2013. 4000 Years of Migration and Cultural Exchange: The Archaeology of the Batanes Islands, Northern Philippines. Terra Australis 40. Canberra: ANU Press. 
Blust, R. 1984-1985. The Austronesian homeland: A linguistic perspective. Asian Perspectives 26: 45-67.

1995. The prehistory of the Austronesian-speaking peoples: A view from language. Journal of World Prehistory 9: 453-510. doi.org/10.1007/BF02221119.

1996. Beyond the Austronesian homeland: The Austric hypothesis and its implications for archaeology. In W. Goodenough (ed.), Prehistoric Settlement of the Pacific, pp. 117-140. Philadelphia: American Philosophical Society.

Bronk Ramsey, C. 2014. Oxcal 4.2 Manual. c14.arch.ox.ac.uk/oxcal.html.

Buì C.H. 2009. Không gian văn hoá Sa Huỳnh: nhận thức từ di chỉ Hoa Diêm Khánh Hoà (Space of Sa Huynh culture: Awareness from Hoa Diem site, Khanh Hoa). Khảo Cồ Học (Archaeology) (5): 67-75.

Buì C.H. and M. Yamagata. 2004. Khu di tích Bình Yên và văn hoá Sa Huỳnh ở Quảng Nam (The Binh Yen site complex and Sa Huynh culture in Quang Nam), In Trung Tâm Nghiên Cứu Khảo Cỗ Học, Viện Khoa Học Xã Hội tại Thành Phố Hồ Chí Minh (Center for Archaeology, Institute of Social Sciences in Ho Chi Minh City) (ed.), Một sô vân dề khảo cồ học ở miền nam Việt Nam (Some Archaeological Achievements in Southern Vietnam), pp. 83-121. Ha Noi: Nhà Xuât Bản Khoa Học Xã Hội (Social Sciences Publishing House).

Bùi C.H., M. Yamagata, K.D. Nguyen. 2010. Excavations of Hoa Diem, 2007 and 2010 seasons (with Vietnamese translation: Khai Quật Hòa Diêm năm 2007 và năm 2010). In Sở Văn Hóa, Thể Thao và Du Lịch Khánh Hòa (Khanh Hoa Culture, Sports and Tourism Office) (ed.), Kỷ Yêu Hội Thảo Khoa Học Khảo Cồ Học Khánh Hòa (Proceedings of Scientific Forum on Archaeology of Khanh Hoa), pp. 90-104. Nha Trang.

Bùi, V.L. 2005. Mộ táng Lung Leng (Lung Leng burials). Khảo Cồ Học (Archaeology) (5): 15-26.

Bùi, V.L, Đ.C. Nguyen, C.B. Nguyen and T. Nguyen. 2005. Báo cáo khai quât di tích Hòa Diêm (Excavation Report of the Hoa Diem Site). Hà Nội: Tư liệu Thư viện, Viện Khảo Cỗ Học (Document of the Library, Institute of Archaeology).

Bùi, V.L., N.Q. Nguyen, and Đ.C. Nguyen. 2008. Di tích Cồn Ràng, Thừa Thiên Huê (The Con Rang site in Thua Thien Hue Province). Khảo Cồ Học (Archaeology) (5): 61-87.

Chử, V.T. and Đào L.C. 1978. Khai quật di tích Long Thạnh (Excavation of the Long Thanh site). In Viện Khoa Học Xã Hội tại Thành Phô Hồ Chí Minh (Institute of Social Sciences in Ho Chi Minh City) (ed.), Nhũ̃ng Phát Hiện Khảo Cồ Học ở Miền Nam (Some Archaeological Discoveries in Southern Vietnam), pp. 196-224. Ho Chi Minh City: Viện Khoa Học Xã Hội tại Thành Phố Hồ Chí Minh (Institute of Social Sciences in Ho Chi Minh City).

Colani, M. 1937. Necropole de Sa Huỳnh. Cahiers de l'École Française d'Extrême-Orient 13: 8-12.

Cuong, N.L. 1986. Two early Hoabinhian crania from Thanh Hoa province, Vietnam. Zeitschrift für Morphologie und Anthropologie 77: 11-17.

2006. About the ancient human bones at An Son (Long An) through the third excavation. Khao Co Hoc (Archaeology) (6): 39-51 (in Vietnamese with English title and summary).

—. 2007. Paleoanthropology in Vietnam. Khao Co Hoc (Archaeology) (2): 23-41.

—_. in press. Địa điểm Gò Ô Chùa (Long An). In Các Nhóm Loại Hình Nhân Chủng Ỏ̉ Việt Nam Và Vấn Đề Nguồn Gốc Người Việt. Đề Tài Khoa Học Cấp Bộ, pp. 424-467.

Đặng, V.T and Q.H. Vũ. 1997. Excavation of Giong Ca Vo site (Can Gio District, Ho Chi Minh City). Journal of Southeast Asian Archaeology 17: 30-44. 
Đặng, V.T., Q.H. Vũ, T.H. Nguyễn, T.P. Ngô, K.D. Nguyen and L.C. Nguyen. 1998. Khảo cồ học tiền sử và sơ sử Thành Phô Hồ Chí Minh (Prehistoric and protohistoric archaeology of Ho Chi Minh city). Ho Chi Minh City: Nhà Xuât Bản Trẻ (The Youth Publishing House).

Debets G.F. 1951. Anthropological studies in the Kamchatka region. Trudy Institute of Ethnography, n.s. 17: 1-263 (in Russian).

Demeter, F.T., E. Sayavongkhamdy, Patole-Edoumba, A.S. Coupey, A.M. Bacon, J. DeVos, C. Tougard, B. Bouasisengpaseuth, P. Sichanthongtip and P. Duringer. 2009. Tam Hang rockshelter: Preliminary study of a prehistoric site in Northern Laos. Asian Perspectives 48: 291-308. doi.org/10.1353/ asi.2009.0000.

Đình, B.H. 2002. Động Cườm - Di tich văn hoá Sa Huỳnh ở Bình Định (Dong Cuom - a site of Sa Huynh culture in Binh Dinh). Khảo Cồ Học (Archaeology) (2): 57-74.

Đoàn, N.K. 2002. Di tích Xóm Ốc (Cù Lao Ré - Quảng Ngãi) và di tích Bãi Ông (Cú Lao Chàm Quảng Nam): Tư liệu và nhận thức (Xom Oc site at $\mathrm{Cu}$ Lao Re and Bai Ong site at Cu Lao Cham: data and perception). Khảo Cô Học (Archaeology) (2): 75-100.

Đoàn, N.K. 2012. Phát hiện mới một số di tích văn hoá Sa Huỳnh tại tỉnh Quảng Ngãi (New discoveries of some Sa Huynh culture sites in Quang Ngai Province). Nhĩng Phát Hiện Mới Về Khảo Cồ Học năm 2011 (New Discoveries of Archaeology in 2011): 278-280.

Favereau, A. 2015. Interactions et modalités des échanges en Mer de Chine méridionale (500 avant notre ère - 200 de notre ère) : approche technologique des assemblages céramiques. $\mathrm{PhD}$ thesis, Muséum National d'Histoire Naturelle, Paris, France.

Fontaine, H. 1972. Nouveau champ de jarres dans la province de Long Khanh. Bulletin de la Société des Études Indo-Chinoises 47(3): 398-467.

Fontaine, H. and T.T. Hoang. 1975. Nouvelle note sur le champ de jarres funéraires de Phu Hoa, avec une remarque sur la crémation au Viet Nam. Bulletin de la Société des Études Indo-chinoises 50(1): $7-73$.

Francken, M. and J. Wahl. 2010. Reflections of a hard life - Burials from Go O Chua (Vietnam). In C. Buhl, F. Engel, L. Hartung, M. Kästner, A. Rüdell and C. W. Freiburg (eds), Proceedings of the fourth Meeting of Junior Scientists in Anthropology, pp. 16-23. Freiburg: University of Freiburg.

Gorman, C.F. and P. Charoenwongsa. 1976. Ban Chiang: A mosaic of impressions from the first two years. Expedition 18: 14-26.

Glover, I. and C.F.W. Higham. 1996. New evidence for early rice cultivation in South, Southeast and East Asia. In D.R. Harris (ed.), The Origins and Spread of Agriculture and Pastoralism in Eurasia, pp. 413-441. London: UCL Press.

Hà V.T. 1983. Suy nghĩ về Sa Huỳnh và từ Sa Huỳnh (Thinking about the Sa Huymh culture). Thông Báo Khoa Học Bảo Tàng Lịch Sử Việt Nam (Scientific Report, Vietnam National Museum of History) (1): 45-50.

- 1984-1985. Prehistoric pottery in Vietnam and its relationships with Southeast Asia. Asian Perspectives 26(1): 135-146.

(ed.). 1999. Khảo Cồ Học Việt Nam Tập II Thời Đại Kim Khi Việt Nam (Vietnamese Archaeology vol. II. Metal Age of Vietnam). Hà Nội: Nhà Xuât Bản Khoa Học Xã Hội (Social Sciences Publishing House). 
Higham, C.F.W. 1998. Archaeology, linguistics and the expansion of the East and Southeast Asian Neolithic. In R. Blench, and M. Spriggs (eds), Archaeology and Language II: Archaeological Data and Linguistic Hypotheses, pp. 103-114. London: Routledge. doi.org/10.4324/9780203202913_ chapter_3.

—. 2002. Early Cultures of Mainland Southeast Asia. Bangkok: River Books.

Hoàng, T.Q. 2010. Đồ gốm văn hóa Sa Huỳnh (Pottery of the Sa Huynh culture). Khảo Cồ Học (Archaeology) (1): 57-73.

Huard, P. and E. Saurin. 1938. État Actuel de la Craniologie Indochinoise. Bulletin du Service Géologique de l'Indochine XXV (in French).

Huson, D.H. and D. Bryant. 2006. Application of phylogenetic networks in evolutionary studies. Molecular Biology and Evolution 23: 254-267. doi.org/10.1093/molbev/msj030.

IHIA (Institute of History and Institute of Archaeology) and CASS (Chinese Academy of Social Science) (eds). 1982. Contributions to the Study on Human Skulls from the Shang Sites at Anyang. Beijing: Cultural Relics Publishing House (in Chinese with English summary).

Institute of Archaeology, Chinese Academy of Social Science (IACAS), the Archaeological Team of the Guangxi Zhuang Municipality (ATGZM), the Zengpiyan Museum (ZM) and the Archeological Team of Guilin City (ATGC). 2003. Zengpiyan - a Prehistoric Site in Guilin. Archeological Monograph Series Type D No. 69. Beijing: Cultural Relics Publishing House (in Chinese with English title and abstract).

Ishii, A. 2010. Classification of the pottery of the Sa Huynh culture found in Quang Nam province, Central Vietnam: Towards new perspectives. Sokou 28: 1-20 (in Japanese).

Janse, O.R.T. 1941. An archaeological expedition to Indo-China and the Philippines. Harvard Journal of Asiatic Studies 6(2): 247-267.

Lâm, M.D. 1998. The Sa Huynh Culture in Hoi An. Southeast Asian Archaeology 1996 Proceedings of the 6th International Conference of the European Association of Southeast Asian Archaeologists, pp. 13-25. Hull: Centre for South-East Asian Studies.

- 2009. Regional and inter-regional interactions in the context of Sa Huynh culture: with regards to the Thu Bon Valley in Quangnam province, Vietnam. Bulletin of the Indo-Pacific Prehistory Association 29: 68-75.

2011. Central Vietnam during the period from 500 BCE to CE 500. In P.-Y. Manguin, A. Mani, and G. Wade (eds), Early Interactions between South and Southeast Asia, pp. 3-15. Singapore: Institute of Southeast Asian Studies.

Lâm, M.D., C. Nguyen and A.T. Hoàng. 2001. Khai quật Gò Dừa năm 1999 (Excavation at Go Dua in 1999). Khảo Cồ Học (Archaeology) (1): 68-80.

Lê, V.C., and V.M. Đinh. 2013. Khai quật Hòa Diêm năm 2011 (Excavation of Hoa Diem, 2011). Thông Báo Khoa Học, Bảo Tàng Lịch Sử Quôc Gia Việt Nam (Scientific Report, Vietnam National Museum of History): 18-32.

Malleret, L. 1959. Indochina. Asian Perspectives 3(1-2): 113-120.

Mansuy, H. and M. Colani. 1925. Contribution à l'étudede la préhistoire de l'Indochine VII. Néolithique inférieur (Bacsonien) et Néolithique supérieur dans le Haut-Tonkin. Bulletin du Service Géologique de l'Indochine 12: 1-45. 
Matsumura, H. and M.J. Hudson. 2005. Dental perspectives on the population history of Southeast Asia. American Journal of Physical Anthropology 127: 182-209. doi.org/10.1002/ajpa.20067.

Matsumura, H. and L.C. Nguyen. 2013. Human skeletal remains from the Hoa Diem site. In M. Yamagata, C.H. Bùi and K.D. Nguyễn (eds), The Excavation of Hoa Diem in Central Vietnam. Bulletin 17. Tokyo: Showa Women's University Institute of International Culture.

Matsumura, H. and M.F. Oxenham. 2013. Population Dispersal from East Asia into Southeast Asia. In K. Pechenkina and M.F. Oxenham (eds), Bioarchaeological Perspectives on Migration and Health in Ancient East Asia, pp. 179-210. Florida: University of Florida Press. doi.org/10.5744/ florida/9780813044279.003.0008.

- 2014. Demographic transitions and migration in prehistoric East/Southeast Asia: through the lens of nonmetric dental traits. American Journal of Physical Anthropology 155: 45-65. doi.org/10.1002/ ajpa.22537.

- 2015. Eastern Asia and Japan: human biology. In P. Bellwood (ed.), The Global Prehistory of Human Migration, pp. 217-223 New York: Wiley-Liss.

Matsumura, H., M.F. Oxenham and L.C. Nguyen. 2015. Hoabinhian: key population with which to debate the peopling Southeast Asia. In Y. Kaifu, M. Izuho, T. Goebel, H. Sato and A. Ono (eds), Emergence and Diversity of Modern Human Behavior in Palaeolithic Asia, pp. 117-132. Texas: Texas A\&M University Press.

Matsumura, H., M.F. Oxenham, K.T. Nguyen, L.C. Nguyen and K.D. Nguyen. 2011. The population history of mainland Southeast Asia: two layer model in the context of Northern Vietnam. In N. Enfield (ed.), Dynamics of Human Diversity: the Case of Mainland Southeast Asia, pp. 153-178. Canberra: Pacific Linguistics.

Nakahashi, T. and M. Li (eds). 2002. Ancient People in the Jiangnan Region, China. Fukuoka: Kyushu University Press.

Nishimura, M. and K.D. Nguyen 2002. Excavation of An Sơn: A Neolithic mound site in the middle reach of the Vàm Cỏ Đông river, Southern Vietnam. Bulletin of the Indo-Pacific Prehistory Association 22: 101-109.

Ngồ, S.H. 1980. Bình Châu (Nghĩa Bình) - dạng di tích mới biêt về thời đại đồng ven biền miền Trung (Binh Chau, Nghia Binh Province: a newly researched Bronze Age site located in the coastal area of Central Vietnam). Khảo Cồ Học (Archaeology) (1): 68-74.

Nguyen, C.B., S. Trịnh, V.C. Quang, Q.H. Vũ, V.H. Phạm and N.T. Phong. 1993. Văn Hóa Xòm Cồn với tiền sử và sơ sử Khánh Hòa (The Xom Con culture, with prehistory and protohistory of Khanh Hoa). Viện Bảo Tàng Lịch Sử Việt Nam - Sở Văn Hóa Thông Tin Kháng Hòa (Vietnam National Museum of History - Khanh Hoa Culture and Information Office), Nha Trang.

Nguyen, C.T., V.A. Trần, Đ.M. Nguyen and A. Trần (eds). 2004. Văn Hóa Sa Huỳnh ở Hội An (The Sa Huynh culture in Hoi An). Hội An: Uy Ban Nhân Dân Thị Xã Hội An, Trung Tâm Quản Lý Di Tích Hội An (People’s Committee of Hoi An, Hoi An Center for Heritage Management).

Nguyen, K.D. 2005; Di chỉ Gò Cấm và con đường tiêp biên văn hoá sau Sa Huỳnh khu vực Trà Kiệu (Go Cam site and post-Sa Huynh acculturation at Tra Kieu area). Khảo Cồ Học (Archaeology) (6): 35-65.

Nguyen, K.S. 2005. Di chỉ Lung Leng nhạn thức bước đầu (Lung Leng site, initial perception). Khảo Cồ Học (Archaeology) (5): 3-14. 
— 2010. Văn Hóa Sa Huỳnh - Văn Hóa Lung Leng những mối liên hệ (Sa Hunh and Lung Leng Cultures - relationships). Khảo Cồ Học (Archaeology) (5): 64-78.

Oxenham, M.F., H. Matsumura and K.D. Nguyen (eds). 2011. Man Bac: The Excavation of a Late Neolithic Site in Northern Vietnam. Terra Australis 33. Canberra: ANU E Press.

Parmentier, H. 1925. Dépots de jarres à Sa-Huynh (Quang-ngai, Annam). Bulletin de l'Ecole Française d'Extrême Orient 23: 325-343.

Pham, T.N. 2000. Recent discovery and excavation of a Sa Huynh culture sites on Ly Son Island, Central Vietnam. Bulletin of the Indo-Pacific Prehistory Association 19: 61-64.

— 2014. Di tích mộ chum Động Cườm (Bình Định) - Tư liệu và nhận thức qua cuộc khai quật lần thứ 2 (The jar burial site of Dong Cuom - documents and new insights from the second excavation). Thông Báo Khoa Hoc Bảo Tàng Lịch Sủ Việt Nam (Scientific Report, Vietnam National Museum of History) 2014(2): 59-77.

Pietrusewsky, M. and M.T. Douglas. 2002. Ban Chiang, A Prehistoric Village Site in Northeast Thailand I: The Human Skeletal Remains. Philadelphia: University of Pennsylvania, Museum of Archaeology and Anthropology.

Reinecke, A., C. Nguyen, and T.M.D. Lam. 2002. Neue Entdeckungen zur Sa-Huynh-Kulter (Nhung phat hien moi ve van hoa Sa Huynh.). Köln: Linden Soft.

Saurin, E. 1973. La champs de jarres de Hang Gon, près Xuan Loc. Bulletin de l'Ecole française d'Extrême Orient 60: 329-358. doi.org/10.3406/befeo.1973.5148.

Sieveking, G.G. 1954. Excavations at Gua Cha, Kelantan, Part 1. Federation Museums Journal 1: 75-143.

Sở Văn Hóa Thông Tin Quảng Nam - Đà Nãng (Culture and Information Office of Quang Nam -

Da Nang Province). 1985. Nhũng di tích thời tiền sủu và so sủ Quảng Nam-Đà Nãng (Prehistric and Protohistoric sites in Quang Nam - Da Nang). Quảng Nam - Đà Nãng.

Solheim, W. 1957. The Kalanay Pottery Complex in the Philippines. Artibus Asiae vol. XX, 4: 279-288. . 1959a. Introduction to Sa-huỳnh. Asian Perspectives 3(1-2): 98-108.

- 1959b. Further notes on the Kalanay Pottery Complex in the Philippines. Asian Perspectives 3(1-2): 157-165.

—. 1959c. Sa Huỳnh related pottery in Southeast Asia. Asian Perspectives 3(1-2): 177-188.

- 1964. Further relationships of the Sa-Huỳnh-Kalanay Pottery Tradition. Asian Perspectives 8(1): $196-211$.

1967. The Sa-huynh-Kalanay Pottery Tradition: past and future research. In M.D. Zamora (ed.), Studies in Philippine Anthropology, pp. 151-174. Quezon City: Alemar-Phoenix Publishing House.

- 1984-1985. The Nusantao hypothesis: the origins and spread of Austronesian speakers. Asian Perspectives 26(1): 77-88.

1992. Nusantao traders beyond Southeast Asia. In I. Glover, P. Suchitta and J. Villiers (eds), Early Metallurgy, Trade and Urban Centers in Thailand and Southeast Asia, pp. 199-225. Bangkok: White Lotus.

2002. (1964) Archaeology of Central Philippines. Revised edition. Quezon City: University of the Philippines. 
- 2006. Archaeology and Culture in Southeast Asia: Unravelling the Nusantao. Quezon City: University or the Philippines Press.

Suzuki, T. 2011. Typological study of a burial jar in Central Vietnam. Bulletin of the Graduated Division of Letters, Arts and Sciences of Waseda University 57-IV: 97-115 (in Japanese).

Tanaka, K. 1987. Rethinking the pottery found in Kalanay Cave, the Philippines: with special reference to the 'sloping-S' incised pattern. Jöchi Shigaku (Sophia Historical Studies) 32: 141-143 (in Japanese).

Trần, A., V.A Trần, and C.T. Nguyen. 2004. Đồ gốm trong các di tích văn hóa Sa Huỳnh ở Hội An (Pottery of the Sa Huynh cultural sites in Hoi An). In C.T. Nguyen, V.A. Trân, Đ.M. Nguyen and A. Trân (eds), Văn Hóa Sa Huỳnh ở Hội An (Sa Huynh Culture in Hoi An), pp. 112-127. Hội An: Uy Ban Nhân Dân Thị Xã Hội An, Trung Tâm Quản Lý Di Tích Hội An (People’s Committee of Hoi An, Hoi An Center for Heritage Management).

Vũ C.Q. 1991. Văn Hoá Sa Huỳnh (The Sa Huynh Culture). Hà Nội: Nhà Xuât Bản Văn Hoá Dân Tộc (National Culture Publishing House).

Yamagata, M. 2006. Inland Sa Huynh culture along the Thu Bon River Valley in Central Vietnam. In E. Bacus, I. Glover and V. Piggot (eds), Uncovering Southeast Asia's Past, pp. 168-183. Singapore: NUS Press.

- 2007a. Origin of jar burials in Vietnam: a preliminary view. Bulletin of the Graduate Division of Letters, Arts and Sciences of Waseda University 52-IV: 97-115 (in Japanese).

—. 2007b. The early history of Lin-i viewed from archaeology. Acta Asiatica 92: 1-30.

- 2009. Sa Huynh culture and the human migration hypothesis in Southeast Asia. In T. Shinkawa, and R. Takahashi (eds), Higashi Ajia no Rekishi, Minzoku, Kōko (History, Ethnology and Archaeology in Eastern Asia), pp. 320-354. Tokyo: Yuzankaku Shuppan (in Japanese).

- 2010. Reconsidering the Sa Huynh - Kalanay Pottery Tradition. In K. Imamura (ed.), Nankai wo Meguru Kōkogaku (Archaeology around the South Seas), pp. 95-129. Tokyo: Dōseisha (in Japanese).

- 2011. Tra Kieu during the second and third centuries CE: the formation of Linyi from an archaeological perspective. In T.K. Phuong and B.M. Lockhart (eds), The Cham of Vietnam: History, Society and Art, pp. 81-101. Singapore: NUS Press.

- 2013. Some thoughts on the Sa Huynh and related pottery. In M. Yamagata, C.H. Bùi and K.D. Nguyễn (eds), The Excavation of Hoa Diem in Central Vietnam, pp. 261-268. Bulletin 17. Tokyo: Showa Women's University Institute of International Culture.

Yamagata, M., D.M. Pham and C.H. Bui. 2001. Western Han bronze mirrors recently discovered in Central and Southern Vietnam. Bulletin of the Indo-Pacific Prehistory Association 21: 91-106.

Yamagata, M., C.H. Bùi and K.D. Nguyễn (ed.). 2013. The Excavation of Hoa Diem in Central Vietnam. Bulletin 17. Tokyo: Showa Women's University Institute of International Culture. 
This text is taken from New Perspectives in Southeast Asian and Pacific Prehistory, edited by Philip J. Piper, Hirofumi Matsumura and David Bulbeck, published 2017 by ANU Press, The Australian National University, Canberra, Australia. 